Fitofarmaka, Vol.9, No.1, Juni 2019 ISSN:2087-9164

\title{
HUBUNGAN KESESUAIAN ANTIBIOTIK DEFINITIF DENGAN CLINICAL OUTCOME PADA PASIEN ULKUS DIABETIK DI RSUD KOTA YOGYAKARTA
}

\author{
Sugiyono, Padmasari \\ Program Studi Farmasi, Fakultas Kesehatan, Universitas Jenderal Achmad Yani \\ Email: nano2saras@gmail.com
}

\begin{abstract}
ABSTRAK
Ulkus diabetik yang mengalami infeksi memerlukan terapi antibiotik yang tepat. Pemberian terapi antibiotik sebaiknya berdasarkan hasil uji kultur bakteri dan sensitivitas antibiotik. Fakta-fakta di lapangan menunjukkan bahwa pola bakteri penyebab ulkus diabetik dan sensitivitas antibiotiknya berbeda-beda di setiap rumah sakit. Hal ini menjadi perhatian penting karena pemilihan antibiotik yang tidak tepat dapat menyebabkan outcome yang buruk pada pasien dan mempengaruhi resistensi antibiotik. Tujuan penelitian ini adalah untuk mengetahui kesesuaian antibiotik definitif yang digunakan dalam pengobatan ulkus diabetik terhadap hasil uji kultur bakteri dan sensitivitas antibiotik serta mengetahui hubungan kesesuaian penggunaan antibiotik definitif dengan clinical outcome. Penelitian menggunakan rancangan observasional deskriptif-analitik dengan desain kohort retrospektif pada pasien ulkus diabetik di RSUD Kota Yogyakarta periode 1 Januari 2017 - 31 Desember 2017. Data diambil dari rekam medik pasien yang memenuhi kriteria inklusi. Data yang diperoleh kemudian dianalisis dengan menggunakan analisis bivariat dengan software SPSS. Hasil penelitian menunjukkan kesesuaian antibiotik definitif terhadap uji kultur bakteri dan sensitivitas antibiotik yaitu sebesar $61,54 \%$ (16 pasien) sesuai dan 38,46\% (10 pasien) tidak sesuai. Berdasarkan analisis Chi-square hubungan antara kesesuaian antibiotik definitif dengan clinical outcome didapatkan nilai $\mathrm{p}=0,014$ dan nilai $\mathrm{RR}=1,667$. Penggunaan antibiotik definitif yang sesuai dengan hasil uji kultur bakteri dan sensitivitas antibiotik lebih besar dari pada yang tidak sesuai. Terdapat adanya hubungan yang bermakna antara kesesuaian antibiotik definitif dengan clinical outcome.
\end{abstract}

Kata kunci: Antibiotik definitif, clinical outcome, ulkus diabetik

\section{CORRELATION BETWEEN DEFINITIVE ANTIBIOTIC COMPATIBILITY AND CLINICAL OUTCOME ON DIABETIC ULCER PATIENTS IN PUBLIC HOSPITAL OF YOGYAKARTA CITY}

\begin{abstract}
Infected diabetic ulcer needs proper antibiotic therapy. Antibiotic therapy administration should be based on laboratory result of bacterial culture and antibiotic sensitivity. The result in the field shows that the pattern of diabetic bacteria and its antibiotic sensitivity are different in every hospital. This becomes an important matter since the improper antibiotic administration can cause damaging outcome for the patient and carry out antibiotic resistance. The objective of this study is to know the definitive antibiotic compatibility used for diabetic ulcer to the laboratory result of bacterial culture and antibiotic sensitivity as well as the relation between the definitive antibiotic administration and clinical outcome. This study used descriptive-analytic observational design through retrospective cohort design on diabetic ulcer patients in public hospitals of Yogyakarta City from January $1^{\text {st }}, 2017$ to December $31^{\text {st }}, 2017$. The data were taken from the patient medical record that fulfills inclusive criteria. The data were analyzed using bivariate analysis through SPSS software. The result shows that definitive antibiotic compatibility to the laboratory result of bacterial culture and antibiotic sensitivity is $61.54 \%$ (16 patients) compatible and $38.46 \%$ (10 patients) incompatible. Based on chi-square analysis, the
\end{abstract}


correlation between definitive antibiotic compatibility and clinical outcome is 0.014 for $p$ value and 1.667 for RR value. The use of compatible definitive antibiotic of the laboratory result of bacterial culture and antibiotic sensitivity is more superior comparing to the incompatible one. Also, there is a meaningful correlation between definitive antibiotic compatibility and clinical outcome.

Keywords: Definitive antibiotic, clinical outcome, diabetic ulcer

\section{PENDAHULUAN}

Ulkus diabetik yang mengalami infeksi memerlukan terapi antibiotik yang tepat. Pemilihan jenis antibiotik definitif sebaiknya berdasarkan hasil uji kultur bakteri dan sensitivitas antibiotik, serta diarahkan pada antibiotik berspektrum sempit. Penggunaan antibiotik empiris berspektrum luas masih dibenarkan pada keadaan tertentu, selanjutnya dilakukan penyesuaian dan evaluasi setelah ada hasil pemeriksaan kultur bakteri dan sensitivitas antibiotik (Kemenkes RI, 2015).

Pemilihan antibiotik yang tidak tepat dapat menyebabkan outcome yang buruk pada pasien, di samping itu juga dapat memengaruhi pola resistensi antibiotik (ADA, 2011). Berdasarkan penelitian di RSUP Dr. Sardjito Yogyakarta menunjukkan adanya hubungan yang bermakna antara kesesuaian antibiotik definitif terhadap clinical outcome dengan nilai $\mathrm{p}<0,05$ (p $=0,03$ ) (Sugiyono, 2016). Namun hasil berbeda ditunjukkan pada penelitian yang dilakukan di RSUP H. Adam Malik Medan di mana penggunaan antibiotik berdasarkan hasil uji sensitivitas memberikan hasil yang tidak signifikan terhadap clinical outcome pasien dengan nilai $\mathrm{p}>0,05(\mathrm{p}=0,393)$ (Afif et al., 2016).

Kenyataan di lapangan menunjukkan bahwa sensitivitas setiap bakteri terhadap antibiotik berbeda-beda di setiap rumah sakit sehingga perlu diketahui pola bakteri dan sensitivitasnya terhadap antibiotik yang ada di rumah sakit tersebut (Sugianto et al., 2007). Mengacu pada hal tersebut maka perlu dilakukan penelitian terkait hubungan kesesuaian antibiotik definitif dengan hasil uji kultur bakteri dan sensitivitas antibiotik terhadap outcome klinik pasien ulkus diabetik.

\section{METODE PENELITIAN \\ Rancangan Penelitian}

Penelitian menggunakan rancangan penelitian observasional deskriptif-analitik dengan desain kohort retrospektif

\section{Waktu dan tempat penelitian}

Penelitian dilakukan di Instalasi Rekam Medik RSUD Kota Yogyakarta periode Juni - Agustus 2018.

\section{Bahan}

Bahan yang digunakan dalam penelitian ini adalah data rekam medik pasien dan lembar pengumpul data.

\section{Objek Penelitian}

Populasi target dalam penelitian ini adalah semua pasien yang terdiagnosa ulkus diabetik yang menjalani rawat inap di RSUD Kota Yogyakarta. Populasi terjangkau (sampel) dalam penelitian adalah pasien yang terdiagnosa ulkus diabetik yang menjalani rawat inap di RSUD Kota Yogyakarta periode 1 Januari - 31 Desember 2017. Teknik pengambilan sampel yang digunakan adalah purposive sampling.

\section{Kriteria Inklusi} yaitu:

Kriteria inklusi dalam penelitian

a. Pasien rawat inap umur $\geq 18$ tahun dengan diagnosis ulkus diabetik. 
b. Pasien yang menerima terapi antibiotik untuk ulkus diabetik dan telah dilakukan uji kultur bakteri dan uji sensitivitas antibiotik yang diambil berdasarkan hasil laboratorium mikrobiologi terakhir.

c. Pasien dengan catatan rekam medis yang dapat dibaca dan lengkap.

\section{Analisis Data}

Analisis data dilakukan secara deskriptif dengan melihat demografi pasien (umur dan jenis kelamin), penyakit penyerta, gambaran pola bakteri dan pola antibiotik serta kesesuaian antibiotik definitif dengan hasil uji kultur bakteri dan sensitivitas antibiotik yang disajikan dalam bentuk persentase. Analisis bivariat dilakukan dengan uji Chi-square untuk melihat hubungan antara kesesuaian jenis antibiotik definitif terhadap clinical outcome. Tingkat kemaknaan yang digunakan adalah 5\% $(\alpha=0,05)$ dengan Confidence Interval yang ditetapkan adalah $95 \%$.

\section{HASIL DAN PEMBAHASAN Sampel Hasil Uji Kultur Bakteri dan Sensitivitas Antibiotik}

Gambaran sampel hasil uji kultur bakteri dan sensitivitas antibiotik dapat dilihat pada Tabel 1. Data pada tabel dibuat berdasarkan data sampel yang tersedia dilapangan yaitu 156 sampel, namun jumlah sampel yang memenuhi kriteria inklusi hanya sebesar 26 sampel.

Tabel 1. Gambaran sampel hasil uji kultur bakteri terbanyak (Staphylococcus aureus), sensitivitas antibiotiknya terhadap pemberian antibiotik definitif serta outcome terapi pasien ulkus diabetik di RSUD Kota Yogyakarta periode Januari 2017 - Desember 2017

\begin{tabular}{|c|c|c|c|c|c|c|c|c|}
\hline \multirow[t]{2}{*}{ No } & \multirow{2}{*}{$\begin{array}{l}\text { Identitas } \\
\text { Pasien }\end{array}$} & \multicolumn{2}{|c|}{$\begin{array}{l}\text { Uji Sensitivitas Antibiotik } \\
\end{array}$} & \multirow{2}{*}{$\begin{array}{c}\text { Antibiotik } \\
\text { Definitif }\end{array}$} & \multicolumn{2}{|c|}{ Kesesuaian } & \multicolumn{2}{|c|}{ Outcome } \\
\hline & & $\mathbf{S}$ & $\begin{array}{ll}\mathbf{I} & \mathbf{R} \\
\end{array}$ & & Sesuai & Tidak & Baik & Buruk \\
\hline \multirow[t]{10}{*}{12} & $\mathrm{ES} /$ & Gentamisin & Tetrasiklin & Ceftriaxon + & & $\mathrm{V}$ & & $\mathrm{V}$ \\
\hline & Pria/ 47th/ & Eritromisin & Cloramfenikol & Metronidazol & & & & \\
\hline & $70 \mathrm{~kg} /$ & & Ciprofloxasin & & & & & \\
\hline & $170 \mathrm{~cm} /$ & & Penisilin & & & & & \\
\hline & Riwayat & & Cefoxitin & & & & & \\
\hline & Penyakit: & & Cefotaxim & & & & & \\
\hline & CKD & & Levofloxasin & & & & & \\
\hline & & & Ceftriaxon & & & & & \\
\hline & & & Metronidazol & & & & & \\
\hline & & & Cefazolin & & & & & \\
\hline \multirow[t]{9}{*}{16} & $\mathrm{G} /$ & Gentamisin & Penisilin & Ceftriaxon + & V & & V & \\
\hline & Wanita/ & Clindamisin & Metronidazol & Clindamisin & & & & \\
\hline & 53th/ & Tetrasiklin & & & & & & \\
\hline & $50 \mathrm{~kg} /$ & Cloramfenikol & & & & & & \\
\hline & $160 \mathrm{~cm} /$ & Ciprofloxasin & & & & & & \\
\hline & Riwayat & Eritromisin & & & & & & \\
\hline & Penyakit: & Cefoxitin & & & & & & \\
\hline & Hipoalbu & Cefazolin & & & & & & \\
\hline & $\min$, ISK & Ceftriaxon & & & & & & \\
\hline
\end{tabular}

Keterangan: $\mathrm{S}=$ Sensitif, $\mathrm{I}=$ Intermediate, $\mathrm{R}=$ Resisten

\section{Karakteristik subyek penelitian}


Tabel 2. Karakteristik pasien ulkus diabetik di RSUD Kota Yogyakarta periode Januari 2017 - Desember 2017

\begin{tabular}{ccc}
\hline \multicolumn{1}{c}{ Karakteristik } & $\begin{array}{c}\text { Jumlah } \\
(\mathrm{n}=26)\end{array}$ & Persentase (\%) \\
\hline Umur (tahun) & 19 & 73,08 \\
$18-60$ & 7 & 26,92 \\
$>60 \quad$ & 15 & 57,70 \\
Jenis kelamin & 11 & 42,30 \\
Pria & & \\
Wanita & 24 & \\
Penyakit penyerta & & \\
Non infeksi (Chronic Kidney & \\
Disease, Hipoalbuminemia, & & \\
Anemia, Hiperurisemia, Chronic & & \\
Heart Failure, Hipertensi, & & \\
Neuropati) & 2 &
\end{tabular}

\section{Pola bakteri pada pasien ulkus diabetik}

Tabel 3. Gambaran pola bakteri pada ulkus diabetik di RSUD Kota Yogyakarta periode Januari 2017 - Desember 2017

\begin{tabular}{lcc}
\hline Nama Bakteri & Frekuensi $(\mathrm{n}=26)$ & $\%$ \\
\hline Gram negatif & & \\
Klebsiella pneumoniae & 4 & 15,38 \\
Acinetobacter baumannii & 2 & 7,69 \\
Proteus mirabilis & 2 & 7,69 \\
Proteus vulgaris & 1 & 3,84 \\
Enterobacter cloacae & 1 & 3,84 \\
Roultellaornithinolitica & 1 & 3,84 \\
Serratia marcescens & 1 & 3,84 \\
Escherichia coli & 1 & 3,84 \\
Alcaligenes sp & 1 & 3,84 \\
Gram positif & & \\
Staphylococcus aureus & 11 & 42,30 \\
Brevibacillus brevis & 1 & 3,84 \\
\hline Ketranga
\end{tabular}

Keterangan: $n=$ jumlah bakteri yang ditemukan

\section{Pola antibiotik pasien ulkus diabetik}

Tabel 4. Gambaran pola pemberian antibiotik definitif pasien ulkus diabetik di RSUD Kota Yogyakarta periode Januari 2017 - Desember 2017

\begin{tabular}{clccc}
\hline No & & Antibiotik & Jumlah (n) & $\%$ \\
\hline 1 & Ceftriaxon & 11 & 16,67 \\
2 & Metronidazol & 8 & 12,12 \\
3 & Meropenem & 6 & 9,09 \\
4 & Ceftazidim & 4 & 6,06
\end{tabular}




\begin{tabular}{clcc}
5 & Ciprofloxasin & 4 & 6,06 \\
6 & Clindamisin & 3 & 4,54 \\
7 & Cefotaxim & 2 & 3,03 \\
8 & Cotrimoxasol & 2 & 3,03 \\
9 & Levofloxasin & 2 & 3,03 \\
10 & Amikasin & 2 & 3,03 \\
11 & Cefazolin & 1 & 1,51 \\
12 & Gentamisin & 1 & 1,51 \\
13 & Ceftriaxon + Metronidazol & 5 & 7,57 \\
14 & Ceftazidim + Meropenem & 3 & 4,5 \\
15 & Ciprofloxasin + Cefotaxim & 2 & 3,03 \\
16 & Cotrimoxazol + Amikasin & 2 & 3,03 \\
17 & Meropenem + Clindamisin & 2 & 3,03 \\
18 & Ceftriaxon + Levofloxasin & 1 & 1,51 \\
19 & Meropenem + Metronidazol & 1 & 1,51 \\
20 & Ceftriaxon + Clindamisin & 1 & 1,51 \\
21 & Ciprofloxasin + Metronidazol & 1 & 1,51 \\
22 & Gentamisin + Ciprofloxasin & 1 & 1,51 \\
23 & Levofloxasin + Metronidazol & 1 & 1,51 \\
\hline Keterangan: 1 pasien dapat menerima 1 atau lebih antibiotik (tunggal atau kombinasi) &
\end{tabular}

\section{Kesesuaian antibiotik definitif terhadap hasil uji sensitivitas antibiotik}

Tabel 5. Hubungan kesesuaian penggunaan antibiotik definitif terhadap hasil uji sensitivitas antibiotik di RSUD Kota Yogyakarta periode Januari 2017 Desember 2017

\begin{tabular}{ccc}
\hline Kesesuaian & Hasil uji sensitivitas antibiotik \\
antibiotik definitif & $\mathrm{n}$ & $\%$ \\
\hline Sesuai & 16 & 61,54 \\
Tidak sesuai & 10 & 38,46 \\
\hline Keterangan: $\mathrm{n}=$ jumlah sampel & &
\end{tabular}

\section{Hubungan kesesuaian antibiotik definitif terhadap clinical outcome}

Tabel 6. Hasil analisis bivariat Chi-square untuk melihat hubungan kesesuaian antibiotik definitif terhadap clinical outcome.

\begin{tabular}{|c|c|c|c|c|c|c|c|}
\hline \multirow{3}{*}{$\begin{array}{c}\text { Kesesuaian } \\
\text { antibiotik } \\
\text { definitif }\end{array}$} & \multicolumn{4}{|c|}{ Clinical outcome } & \multirow[t]{3}{*}{$\boldsymbol{P}$} & \multirow[t]{3}{*}{$\mathbf{R R}$} & \multirow[t]{3}{*}{$95 \% \mathrm{CI}$} \\
\hline & \multicolumn{2}{|c|}{ Membaik } & \multicolumn{2}{|c|}{ Memburuk } & & & \\
\hline & $\mathbf{n}$ & $\%$ & $\mathbf{N}$ & $\%$ & & & \\
\hline Sesuai & 16 & 100 & 0 & 0 & $0,014 *$ & 1,667 & $1,005-$ \\
\hline Tidak sesuai & 6 & 60 & 4 & 40 & & & 2,765 \\
\hline
\end{tabular}

Keterangan: RR: Relative Risk; CI: Confidence Interval; *Signifikan secara statistik $(\mathrm{p}<0,05)$

\section{PEMBAHASAN}

Dari tabel 1, hasil uji sensitivitas antibiotik dikategorikan dalam Sensitif (S), Intermediate (I) dan Resisten (R) sesuai dengan kriteria yang ditentukan oleh Clinical and Laboratory Standards Institute (CLSI). Evaluasi kesesuaian antibiotik definitif dilakukan dengan 
melihat kesesuaian jenis antibiotik yang diberikan kepada pasien ulkus diabetik terhadap hasil uji kultur bakteri dan sensitivitas antibiotik. Antibiotik definitif dikatakan sesuai apabila antibiotik yang diberikan termasuk dalam jenis antibiotik yang sensitif pada hasil uji sensitivitas. Jika antibiotik yang digunakan lebih dari 1, maka semua antibiotik harus sesuai dengan hasil uji sensitivitas. Antibiotik definitif dikatakan tidak sesuai apabila terdapat minimal 1 antibiotik yang digunakan tidak termasuk dalam jenis antibiotik yang sensitif pada hasil uji sensitivitas.

Tujuan dari pengobatan infeksi ulkus diabetik adalah pemberantasan tanda klinis infeksi serta menghindari hilangnya jaringan lunak dan amputasi. Evaluasi secara menyeluruh harus dilakukan setelah pemberian terapi antibiotik. Pada penelitian ini hasil terapi antibiotik yang dicapai pada pengobatan ulkus diabetik ditetapkan berdasarkan keputusan klinisi yang menilai outcome pasien. Perbaikan atau perburukan kondisi ulkus diketahui dari rekam medik pasien yang terdiri atas jumlah leukosit, nanah, jaringan nekrotik dan suhu tubuh.

Berdasarkan tabel 2, persentase ulkus diabetik banyak terjadi pada pasien dengan umur 18-60 tahun yaitu sebesar $73,08 \%$ (19 pasien) dari pada umur $>60$ tahun sebesar $26,92 \%$ (7 pasien). Hal ini kemungkinan terjadi karena adanya penurunan respon inflamasi, penurunan kemampuan proliferasi sel, perlambatan angiogenesis dan laju sintesis kolagen yang rendah dibanding degradasinya (Minimas, 2007). Pada kelompok jenis kelamin, pria mempunyai proporsi lebih besar terhadap terjadinya ulkus diabetik yaitu sebesar $57,7 \%$ (15 pasien) dibandingkan wanita 42,3\% (11 pasien). Namun, selisih jumlah pasien antara kedua jenis kelamin tersebut tidak banyak dan tidak dapat menunjukkan bahwa pria lebih dominan menderita ulkus diabetik.
Beberapa penelitian lain menyebutkan kelompok wanita mempunyai insidensi lebih besar yaitu 69\% (Ella, 2011); 78,3\% (Akbar et al., 2014). Pada kelompok penyakit penyerta dibagi menjadi 2 yaitu penyakit penyerta non infeksi dan penyakit penyerta infeksi. Berdasarkan pengamatan didapatkan hasil bahwa pasien dengan penyakit penyerta non infeksi sebesar 92,31\% (24 pasien) dan penyakit penyerta infeksi sebesar 7,69\% ( 2 pasien). Penyakit penyerta non infeksi yang paling banyak terjadi adalah Chronic Kidney Disease, anemia, dan hipoalbuminemia.

Berdasarkan tabel 3, hasil kultur bakteri terhadap 26 spesimen pus pasien ulkus diabetik didapatkan hasil 53,84\% (14 sampel) adalah bakteri Gram negatif dan 46,16\% (12 sampel) adalah bakteri Gram positif. Pada penelitian ini Staphylococcus aureus adalah bakteri aerob Gram positif yang paling banyak ditemukan yaitu $42,50 \%$ (11 sampel). Biasanya bakteri Gram positif ditemukan pada ulkus diabetik yang masih akut, sedangkan pada ulkus diabetik kronis, bakteri Gram negatif lebih banyak ditemukan (Zubair et al., 2011).

Dari tabel 4, pola penggunaan antibiotik definitif yang diberikan pada pasien ulkus diabetik adalah terapi antibiotik tunggal dan kombinasi. Di mana terapi antibiotik tunggal yang banyak digunakan adalah ceftriaxon, metronidazol, dan meropenem, sedangkan untuk kombinasi 2 antibiotik yang banyak digunakan adalah ceftriaxon + metronidazol dan ceftazidim + meropenem. Ceftriaxon, ceftazidim, dan meropenem adalah antibiotik dengan spectrum luas yang menjadi antibiotik pilihan dalam pengobatan ulkus diabetik (Lipsky et al., 2012). Ceftriaxon dan ceftazidim digunakan sebagai antibiotik yang mengover infeksi bakteri Gram negatif termasuk Pseudomonas dan mempunyai efikasi yang rendah terhadap 
bakteri Gram positif. Meropenem adalah antibiotik golongan carbapenem yang mempunyai spektrum luas terhadap sebagian besar bakteri Gram negatif dan positif.

Terapi kombinasi antibiotik sering digunakan pada pasien ulkus karena adanya aktivitas yang sinergis antar antibiotik terhadap bakteri Gram positif dan negatif. Metronidazol dan clindamisin sering ditambahkan dalam pemberian kombinasi antibiotik (Lipsky, 2004). Clindamisin diberikan karena mempunyai spektrum yang optimal terhadap bakteri Gram positif cocci dan bakteri anaerob, sedangkan pemberian metronidazol tergantung dari kondisi ulkus pasien, metronidazol langsung diberikan pada pasien dengan ulkus yang sudah kronis, ulkus yang dalam dan mengeluarkan bau (Ella, 2011).

Berdasarkan tabel 5, evaluasi kesesuaian penggunaan antibiotik definitif terhadap hasil uji sensitivitas antibiotik didapatkan hasil $61,54 \%$ (16 pasien) sesuai dan 38,46\% (10 pasien) tidak sesuai. Hasil ini berbeda dengan penelitian di Amerika Serikat, penggunaan antibiotik yang sesuai dengan hasil uji sensitivitas antibiotik hanya sebesar 20-25\%. Beberapa penelitian terkait penggunaan antibiotik menyebutkan bahwa masih banyak masalah terkait theoritical gap antara pedoman antibiotik di rumah sakit dengan literatur yang ada. Hal ini mengindikasikan perlunya penelitian lebih lanjut dalam praktek klinik. Penemuan di rumah sakit pendidikan di Australia menunjukkan bahwa kurang dari 50\% praktek klinik yang mematuhi pedoman penggunaan antibiotik (Restinia et al., 2010).

Dari tabel 6 terlihat bahwa kesesuaian antibiotik definitif pada pasien kelompok sesuai: sebesar $100 \%$ mengalami clinical outcome membaik dan 0\% memburuk, sedangkan pada pasien kelompok tidak sesuai: sebesar $60 \%$ mengalami clinical outcome membaik dan $40 \%$ memburuk. Berdasarkan analisis bivariat Chi-square menunjukkan adanya hubungan yang bermakna antara kesesuaian antibiotik definitif terhadap clinical outcome dengan nilai $\mathrm{p}<0,05(\mathrm{p}$ $=0,014)$. Hal ini berarti terdapat hubungan antara kesesuaian antibiotik definitif (baik kelompok sesuai maupun tidak sesuai) terhadap clinical outcome pasien ulkus diabetik. Di samping itu nilai RR yang diperoleh adalah 1,667 (95\% CI $=1,005-2,765$ ) yang bermakna bahwa pasien dengan antibiotik definitif sesuai mempunyai potensi 2 kali lebih besar untuk mendapatkan clinical outcome membaik dibanding pada pasien yang tidak sesuai.

\section{SIMPULAN}

1. Penggunaan antibiotik definitif yang sesuai dengan hasil uji kultur bakteri dan sensitivitas antibiotik lebih besar dari pada yang tidak sesuai.

2. Terdapat hubungan yang bermakna antara kesesuaian antibiotik definitif dengan clinical outcome, di mana pasien dengan penggunaan antibiotik definitif yang sesuai mempunyai potensi 2 kali lebih besar untuk mendapatkan clinical outcome membaik dibanding pada pasien yang tidak sesuai.

\section{UCAPAN TERIMA KASIH}

Penulis mengucapkan terimakasih kepada Fakultas Kesehatan, Universitas Jenderal Achmad Yani Yogyakarta yang telah memberikan bantuan dana melalui Hibah Penelitian Tahun 2018 dan Plt. Direktur (Sekretaris Dinas Kesehatan Kota Yogyakarta) yang telah memberikan kesempatan kepada penulis untuk melakukan penelitian dan pengambilan data yang diperlukan di RSUD Kota Yogyakarta.

\section{DAFTAR PUSTAKA}


Kemenkes RI. 2015. Peraturan Menteri Kesehatan Republik Indonesia No. 8 Tahun 2015 tentang Program Pengendalian Resistensi Antibiotik. Departemen Kesehatan Republik Indonesia. Jakarta.

Afif, M.H., D.P. Pohan, M. Marshal. 2016. Hubungan pemberian antibiotik berdasarkan hasil uji sensitivitas terhadap pencapaian clinical outcome pasien dengan ulkus diabetik di RSUP Haji Adam Malik Medan. Repositori Institusi. Universitas Sumatera Utara.

Akbar, G.T., J. Karimi, D. Anggraini. 2014. Pola bakteri dan resistensi antibiotik pada ulkus diabetik grade 2 di RSUD Arifin Achmad periode 2012. Jurnal Online Mahasiswa (JOM) Bidang Kedokteran. 1: 1-15.

American Diabetes Association (ADA). 2011. Diagnosis and classification of diabetes mellitus. Diabetes Care. 34(Suppl.1): 62-69.

Ella, Y., 2011. Analisa kesesuaian antibiotik empiris dan definitif terhadap hasil uji sensitivitas dan pustaka terkait perbaikan parameter infeksi pada pasien infeksi ulkus diabetik rawat inap di RSU Haji Surabaya. Tesis. Fakultas Farmasi, Universitas Surabaya.

Lipsky, B.A., 2004. Medical Treatment of diabetic foot infections. Clinical Infectious Diseases. 39(Suppl.): 104-114.

Lipsky, B.A., AR. Berendt, P.B. Cornia, J.C. Pile, E.J.G. Peters, D.G.
Armstrong, D.G., et al., 2012. 2012 Infectious Diseases Society of America clinical practice guideline for the diagnosis and treatment of diabetic foot infections. Clinical Infectious Diseases: An Official Publication of the Infectious Diseases Society of America. 54: e132-173.

Minimas, D.A., 2007. Ageing and its influence on wound healing. Wound $U K, \mathbf{3}(\mathbf{1}): 42-50$.

Restinia, M., H. Lucida, S.W. Gillani. 2010. Longitudinal clinical evaluation of antibiotik use among patients with infecton. International Journal of Pharmacy \& Life Sciences. 3: 1935-1945.

Sugianto, E, R. Riyanto, B. Subakir. 2007. Pola Kuman Ulkus Diabetik di RS. Dr. Kariadi, RSU Kota Semarang, RSU Tugurejo, Semarang. Jurnal Kedokteran Indonesia MEDIKA. 33 (11).

Sugiyono, S. 2016. Evaluasi kesesuaian antibiotik definitif terhadap Clinical Outcome dan gambaran antibiogram pada pasien ulkus diabetik di RSUP Dr. Sardjito Yogyakarta. Tesis. Fakultas Farmasi, Universitas Gadjah Mada.

Zubair, M., A. Malik, J. Ahmad, M. Rizvi, K.J. Farooqui, M.W. Rizvi. 2011. A study of biofilm production by gram-negative organisms isolated from diabetik foot ulcer patients. Biology and Medicine, 3(2): 147157. 